\title{
The calorie requirements of Nigerian peasant farmers
}

\author{
By B. M. NICOL \\ Nutrition Unit, Federal Medical Department, Nigeria
}

(Received 19 November 1958-Revised 9 April 1959)

A report of the Food and Agriculture Organization of the United Nations (F.A.O.: Second Committee on Calorie Requirements, 1957) attempts to express the energy needs of healthy and active human beings in quantitative terms. 'The recommendations are designed for application to countries or fairly large groups of people and not to individuals.' They are based on a reference man of $65 \mathrm{~kg}$ body-weight at 25 years of age, living in the temperate zone at a mean annual external temperature of $10^{\circ}$, and on a reference woman of $55 \mathrm{~kg}$ body-weight living in the same environment. The man is assumed to require a daily average of $3200 \mathrm{kcal}$, and the woman $2300 \mathrm{kcal}$. By allowing for variations in body-weight, age from birth through childhood and adolescence to old age, for differences in external temperature, and for pregnancy and lactation, methods to assess the calorie requirement of any community are set out. The report draws attention to the fact that diets throughout the world differ in digestibility and nutrient composition, and emphasizes that suitable allowances must be made for such variations.

In spite of the Committee's warning that its recommendations are designed for application to fairly large groups of people, an attempt is made in this paper to correlate the calorie value of the diets of certain small rural Nigerian populations with the physiological requirements suggested by the F.A.O. Committee. Another paper considers the question of protein requirements (Nicol, 1959a). The term 'physiological' raises difficulties, as all the communities investigated were infested more or less with intestinal and other parasites, and the Committee's recommendations do not allow for such loads. The incidence of infestation has been indicated, but the people have been considered together with their parasites in comparing the calorie value of their diets with the F.A.O. requirements. In spite of the primitive conditions in which they live it is estimated that the rural communities of Nigeria are increasing in numbers at a rate of approximately $2 \%$ a year (Nicol, $1959 b$ ).

The food-consumption studies here reported were undertaken between 1954 and 1957 in an attempt to determine the general adequacy or otherwise of the Nigerian peasants' diets. They were combined with detailed clinical examinations to establish base-lines from which to judge the future development of the farmers' health, upon which depends the health of the urban populations, and also to provide data that might be of value to the various Nigerian Governments in formulating agricultural policies. The small sample communities studied were carefully selected to be typical of people living in the different vegetation zones of Nigeria. Each collection of compounds, hamlet or village was situated at least 50 miles from a town of 5000 or more 
inhabitants, and at least 15 miles from a main road or railway. In each place all the permanent residents forming the community were examined at the beginning and end of a $I$-year period, and the food consumption of all those people living in at least one-third of the compounds was measured for Io days on three occasions at different seasons of the year. From the data so obtained a mean daily food intake for the year was estimated, and the mean daily calorie value of the diets of children from 4 to 6 years, from 7 to 9 years, from 10 to 12 years and of males and females over 12 years of age was compared with the F.A.O. recommendations.

\section{METHODS}

The people studied. The map (Fig. I) indicates the vegetation zones and the part of Nigeria in which each investigation was carried out. The farmers, cattle-owners and fishermen living in Jarawaji near Lake Chad are of Kanuri and Shuwa Arab stock, who work hard and travel long distances by foot to their fields and markets, as do the farmers living in Tangaza in the north-eastern corner of Nigeria. In Jarawaji the women as well as the men work in the fields and twice or three times weekly carry heavy loads to markets which may be 5 or 20 miles from home. The Tangaza women do not work much outside their compounds. In Tungan Maidubu and Bunga the men are energetic farmers who hunt game in the dry season. The women in Tungan Maidubu work in the fields as well as in the house, but in Bunga they only cultivate small vegetable gardens of sorrel, amaranths and okra near the compounds. The men of the Fiam tribe living in Langai on the high plateau are farmers; their women do not work in the fields, but expend much of their energy brewing beer from sorghum and millet. The staple foods of all the communities mentioned so far are sorghum (Sorghum vulgare Pers.) and bulrush and finger millets (Pennisetum typhoideum Rich. and Eleusine coracana Gaertn.).

In Bero-Okuta and Mbanege the farmers' staple crops are the yams (Dioscorea spp., Colocasia antiquorum Schott and Xanthosoma appendiculatum Schott). The men and women do not have to travel far to their fields, and the women do not have long distances to walk to markets. Life in these hot and humid southern areas is lived at a much slower pace than in the savannah country farther north.

Age. The age was determined by questioning individuals, parents and neighbours, by correlation with well-known local and world events, and by clinical examination. In rural areas where registration of births and deaths is not in force it is impossible to assess age otherwise. It is believed that children up to 15 years have been classified for age reasonably accurately, and that thereafter the 5-year groups used are satisfactory.

Food consumption. The daily food consumption of all the people living in every third compound in the villages was measured for ro days (I) shortly after the harvesting of the staple food, (2) midway between the harvest and the next planting, and (3) at some time in the 2 months before the next harvest. 'The first 2 days' and the last day's records were rejected, as meals on these days tended to be of better than average quantity and quality, and the mean daily food consumption was calculated for the 
remaining 7 days of each period. The rates of consumption obtained were taken to be representative of the particular season, and a weighted daily mean for the year was calculated from the amounts recorded and the duration of each season or the number of weeks or months each foodstuff was available.

All the foods prepared for each meal were weighed before and after cooking, and individual or group helpings were weighed before they were eaten. Any food remaining in cooking pots was weighed. Plate waste was found to be negligible. Members of certain groups, e.g. children 4-6 years and 7-9 years and the young men, often shared the same calabash, in which the soup was poured over the staple food; on these

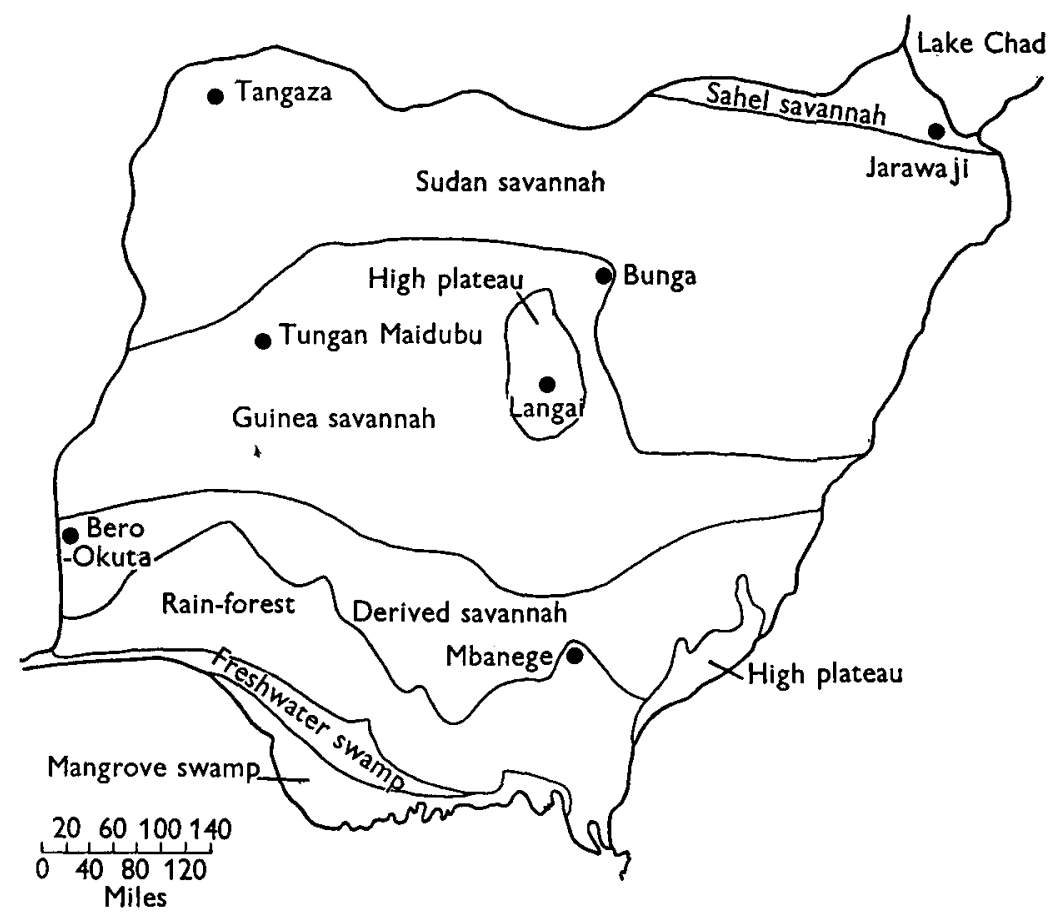

Fig. I. Vegetation zones of Nigeria, showing the situation of the villages in which the studies of food consumption were made.

occasions the individual intake was obtained by dividing the total quantity eaten by the number of consumers. Each individual was questioned before every meal about any food consumed in or outside the compound between meals. Food eaten outside compounds was recorded by direct observation as far as possible. For example, the size of a head of millet or a piece of yam roasted in an ash fire in the farm was judged by eye and a similar article was later weighed and included in the consumer's record. Trained Nutrition Unit and Medical Field Unit personnel carried out the weighing and observing, and all record sheets were checked after each meal and in the evening.

It was impossible to measure the food intake of children from I to 3 years of age, as they consumed varying amounts of breast milk, but food eaten by these children from a mother's dish was deducted from her share. Certain age groups, e.g. the 10-12-year-old Jarawaji and Tangaza children, were so erratic in their eating habits 
that it was impossible to obtain satisfactory records of their food consumption. Women frequently ate together from a communal calabash, so that it was impossible to separate the consumption of pregnant and lactating women from that of the other women.

It was found that the greatest amount of food eaten outside the compound by any individual supplied $30 \%$ of his mean daily calorie intake, but this amount was exceptional. If it is assumed that $20 \%$ of all food eaten was obtained elsewhere than in the compound kitchen, and that the methods of questioning and direct observation used to estimate this amount resulted in an error of $\pm 50 \%$, and that the direct weighing of food consumed at meal times involved an error of $\pm 5 \%$, an overall error in the estimation of individual food intakes of $\pm 15 \%$ can be expected.

The calorie value and nutrient composition of the food consumed by individuals in the different age and sex groups was computed from the F.A.O. tables (Chatfield, 1953, 1954). The calorie factors used in the construction of these tables make allowance for the digestibility of the different foodstuffs. When the necessary information was lacking in the F.A.O. tables reference was made to the tables of the United States Department of Agriculture (Leung, Pecot \& Watt, 1952) and of the Medical Research Council (Platt, I945). Certain foods commonly used in Nigeria which are not included in those tables have been analysed by the Government Chemist in London, and I am indebted to his staff for these data. The proximate composition of other foodstuffs has been determined in the Nutrition Unit laboratories. The F.A.O. and other tables express the calorie value and nutrient composition of foods in terms of the uncooked edible portion. The weight of uncooked food from which the diets were derived was calculated from the weight of individual or group helpings. Cooked helpings of soup of reasonably uniform consistence were measured by volume, and the individual consumption of the uncooked ingredients was calculated by proportion in the same way.

Calorie requirement. The calorie requirement of each age group was calculated by the methods recommended by F.A.O.: Second Committee on Calorie Requirements (1957) on the assumption that activity corresponded to that of the 'reference' man and woman. Allowance was made for body-weight by using formula 3 ,

$$
\begin{aligned}
& E=815+36 \cdot 6 W \text { (men), } \\
& E=5^{80}+3 \mathrm{I} \cdot \mathrm{I} W \text { (women), }
\end{aligned}
$$

where $E$ is the total calorie requirement in kcal and $W$ the weight in $\mathrm{kg}$. Adjustments for age and environmental temperature were made in that order by the method described in the report of the Committee, the mean annual external temperature being taken as $25^{\circ}$ in all parts of Nigeria.

As the calorie allowance for pregnancy and lactation had to be made on an individual basis, the figures given in the report of F.A.O.: Committee on Calorie Requirements (1950) were used, namely $45^{\circ} \mathrm{kcal} /$ day for the last trimester of pregnancy and rooo kcal/day for the first 6 months of lactation. Nigerian peasant women customarily continue breast feeding their children for periods up to, and occasionally exceeding, 2 years. The supply of milk diminishes considerably after 6 months, but 


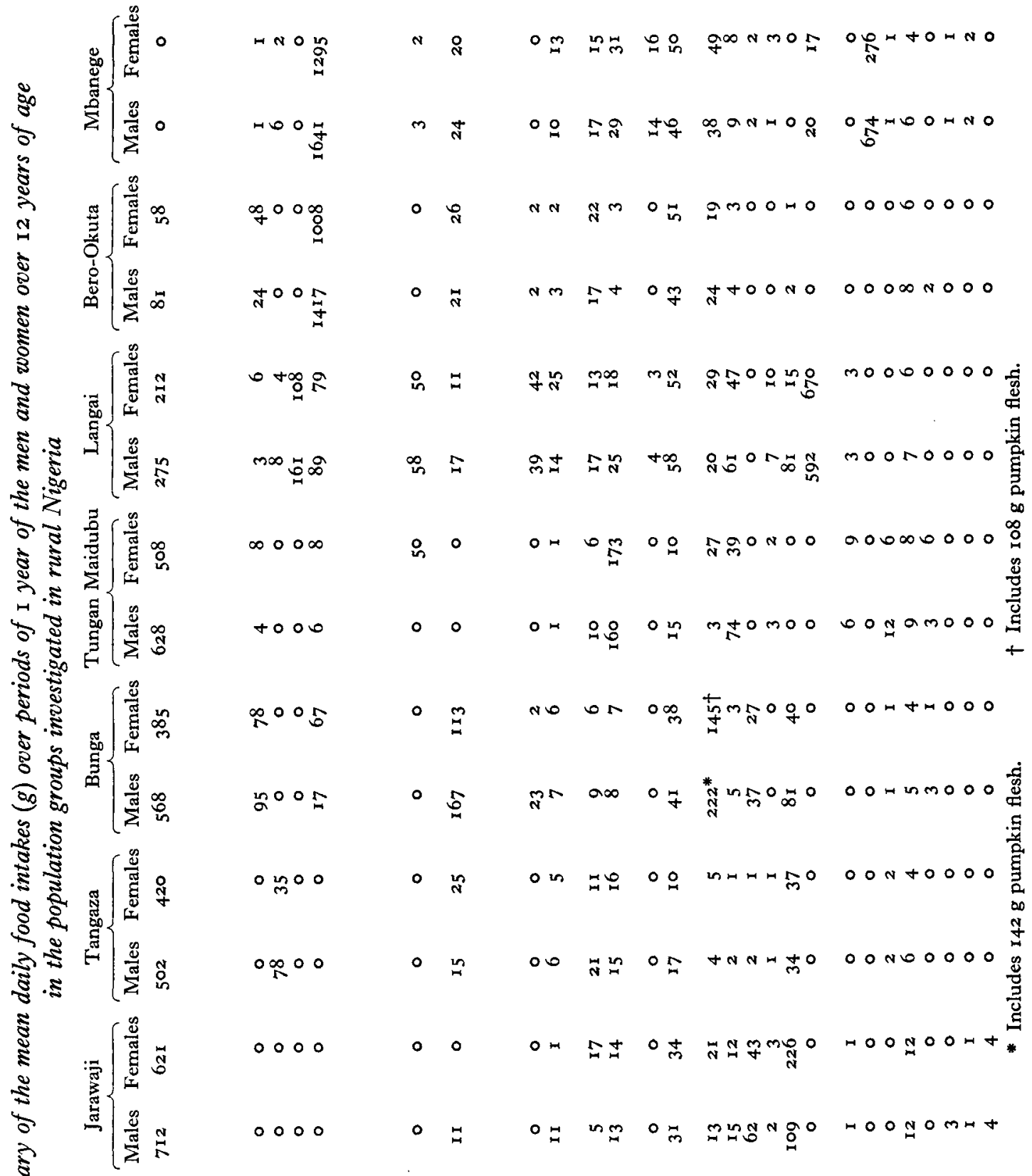

离

i

造

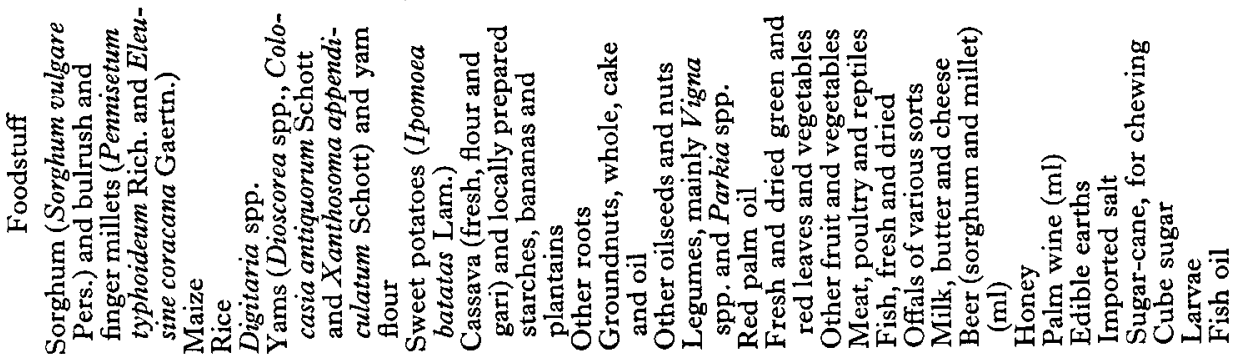




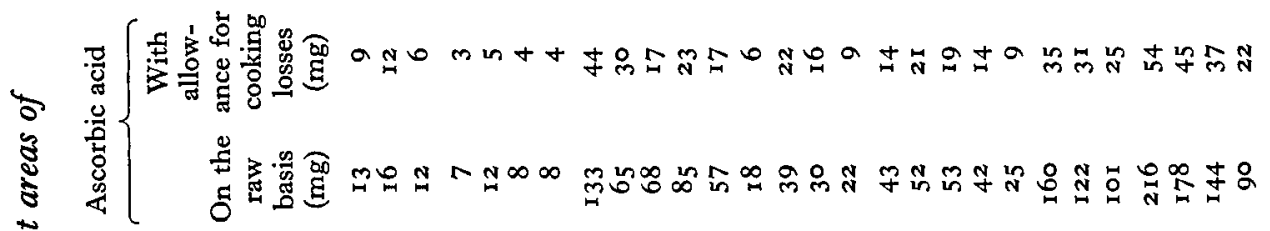

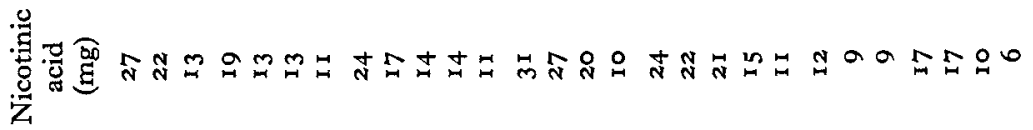

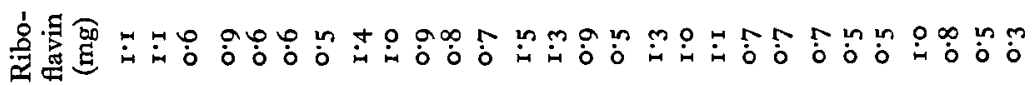

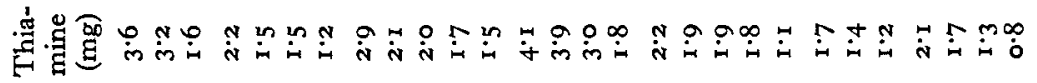

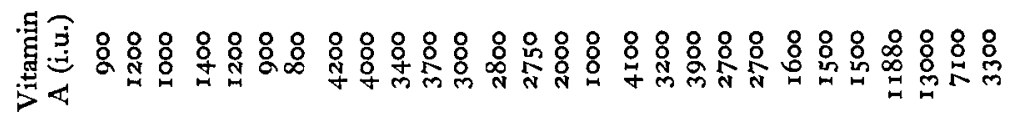

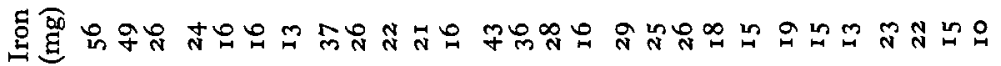

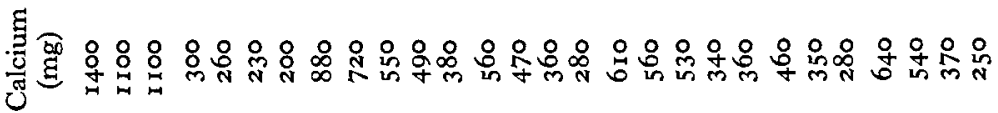

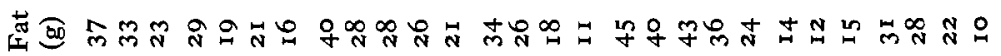
要 赵

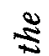
के

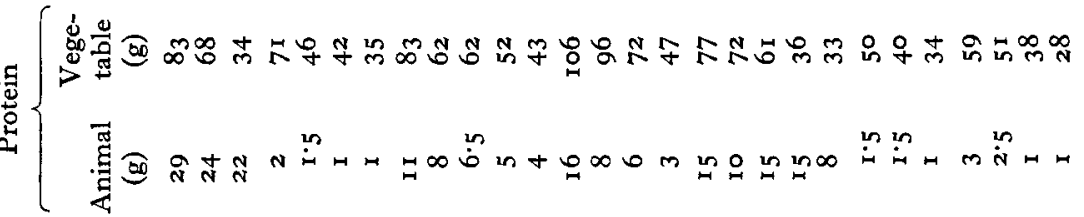

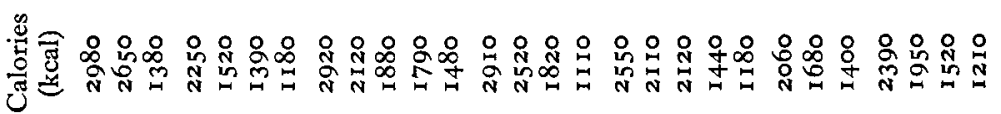

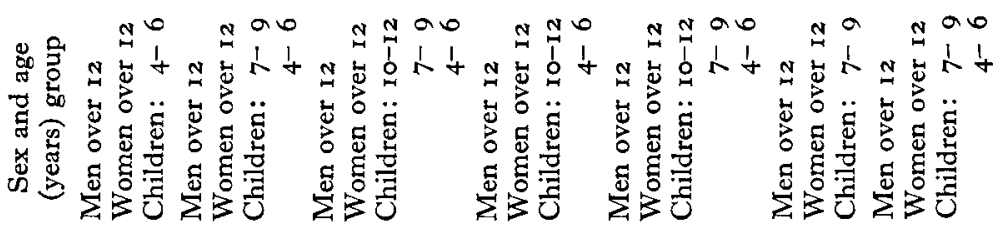
$\dot{4}$

$\frac{0}{\frac{0}{\pi}}$

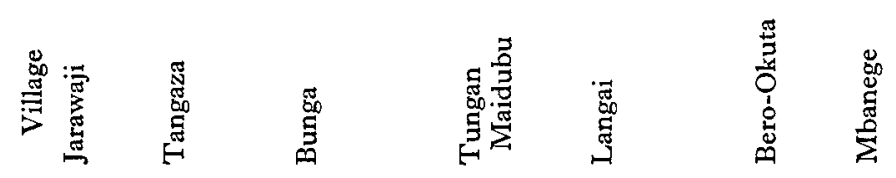




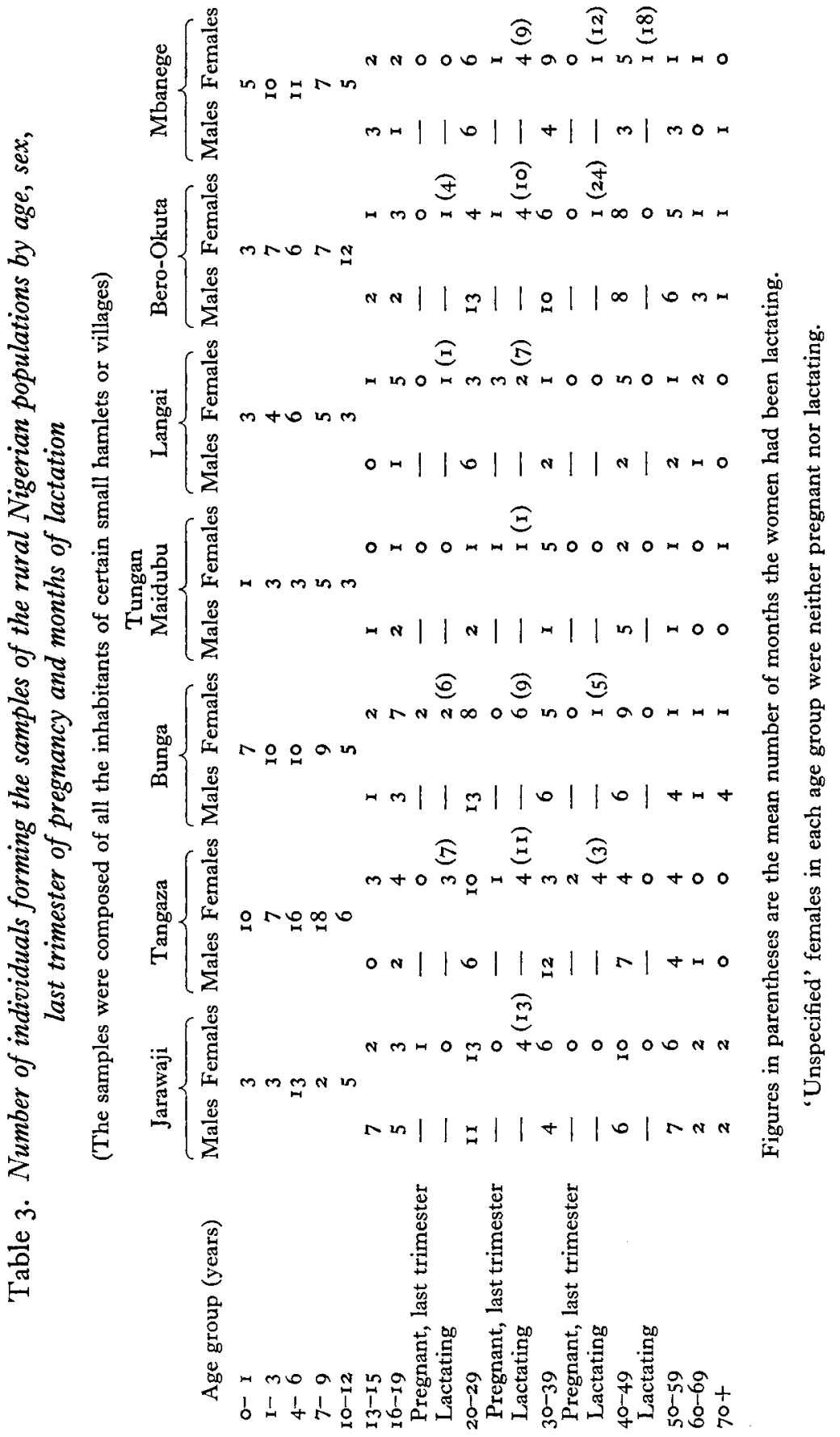




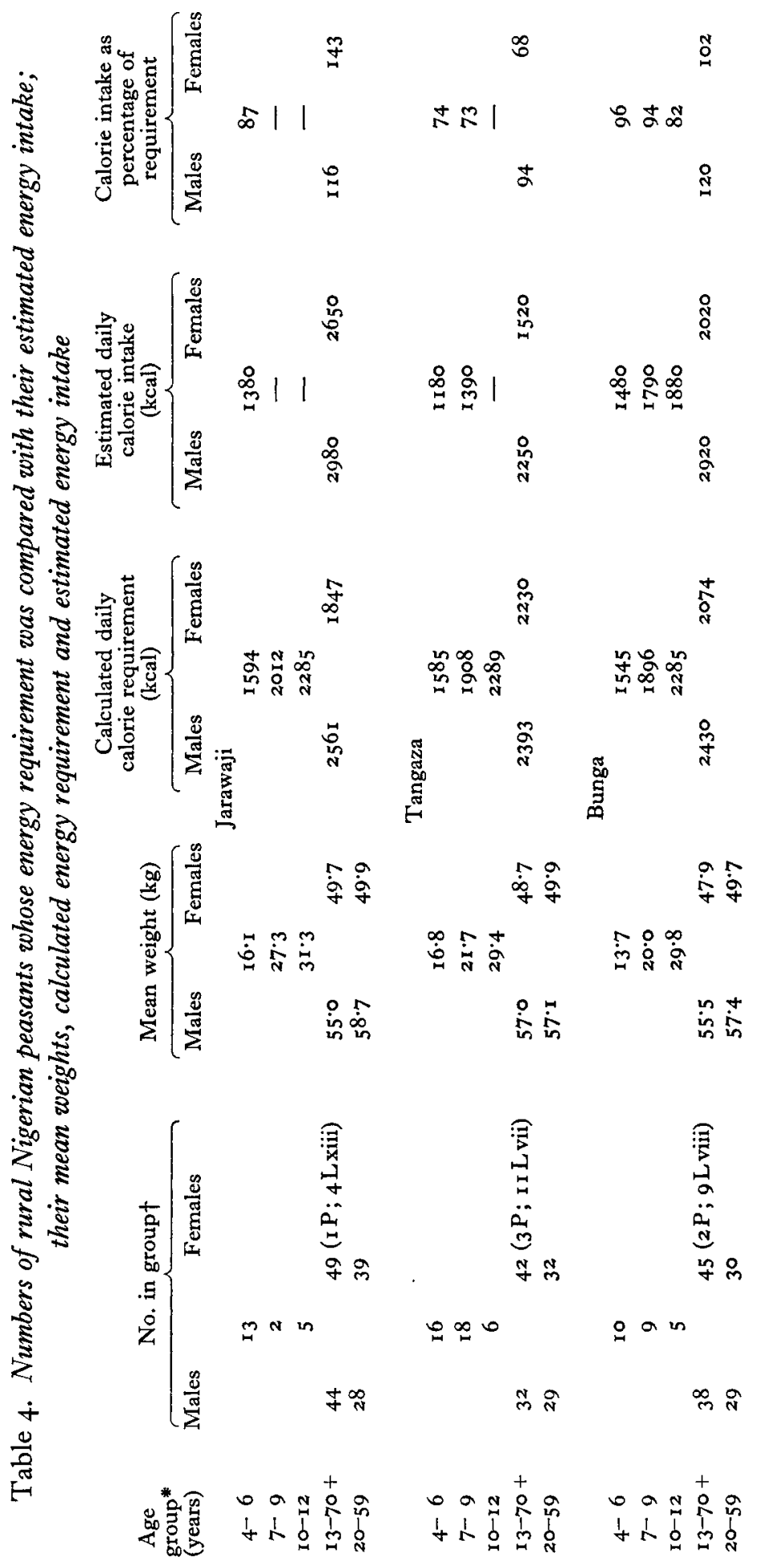




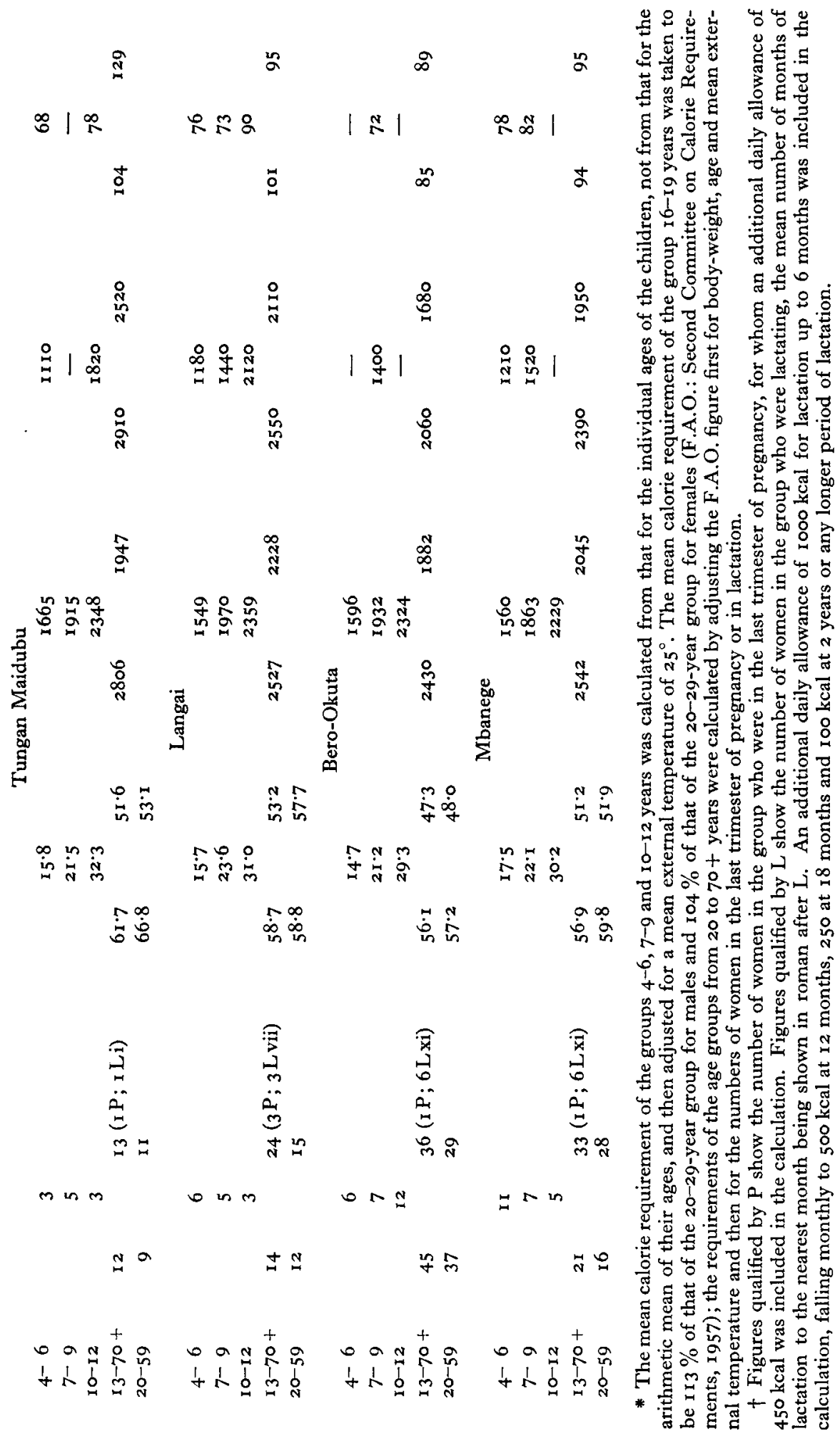


the amount secreted at different stages was not estimated. Therefore the following purely arbitrary figures for the daily calorie requirements resulting from lactation were used: up to 6 months $1000 \mathrm{kcal}$, falling monthly to $500 \mathrm{kcal}$ at I year, $250 \mathrm{kcal}$ at 18 months and $100 \mathrm{kcal}$ at 2 years or longer.

Body-weight. It was measured before the morning meal at the beginning and end of the year, on a spring balance calibrated monthly against Government-inspected weights, the individual wearing only a loin-cloth. The body-weights given in Table 4 are those recorded shortly after the harvest season.

\section{RESULTS}

The estimated mean daily food consumption of those people over 12 years of age in each community throughout the year of investigation is shown in Table $I$, and indicates the general dietary pattern in each area. It is important to point out that in Tangaza the year in question was a poor one, the millet crop having partially failed owing to lack of rain. In all other areas the crops were average or better than average. Overselling of the yam crop, game and other foodstuffs produced in the Bero-Okuta area has become customary since a new motor road was opened 8 years ago linking this part of the country to the populous Yoruba cocoa-growing areas lying to the south. Since then a variable period of food shortage due to lack of sufficient money with which to buy back their crops has been experienced annually by these farmers.

The calorie value and nutrient composition of the diets are given in Table 2.

The numbers of all individuals forming the communities studied is shown in Table 3 , including those women in the last trimester of pregnancy, the number lactating and the mean duration of lactation. The numbers of people in the age groups $4-6,7-9$, 10-12, and $13-70+$ years, their mean weights, calculated calorie requirements and the estimated calorie value of their diets are presented in Table 4, in which the ratio of calorie intake to calorie requirement is shown as a percentage.

The parasitic-infestation rates found in each community by examinations of blood, faeces and urine are shown in Table 5. Malaria was holoendemic in all areas, and the parasitic-infestation rates, which varied in degree from place to place, cannot be assessed satisfactorily in respect of their effect on calorie requirements.

The dietary patterns varied considerably. In Bero-Okuta and Mbanege the staple foods were yams, whereas in the other areas sorghum and millet (mainly Pennisetum) provided the bulk of calories. In the yam-eating communities very little food of animal origin was consumed, but the intake of legumes, nuts, green vegetables and fruit was higher than elsewhere. Meat was eaten in reasonable quantity in Tungan Maidubu and Langai, and fish provided good amounts of protein in Jarawaji and Bunga. Dairy produce was used frequently in Jarawaji, Bunga and Langai, mostly as sour milk or cheese. Sorghum and millet beers were drunk freely in Langai, and palm (Elaeis guineensis) wine in Mbanege. Elsewhere the only regular use of fermentation to enhance the nutritive and contentment value of the diets was in the preparation from locust beans (Parkia clappertoniana) of cakes which were used to flavour soups. Cassava was seldom used by these groups of peasant farmers. 
In areas where sorghum and millet were the staple foods, and where the harvest had been average or better than average, the calorie values of the diets were satisfactory (Table 4). In Tangaza the failure of the millet crop reduced this value below the normal level, which affected particularly the women's diets. The calorie values of the diets in the yam-eating areas were less than in those areas where sorghum and millet were the staple foods.

Table 5. Parasitic-infestation rates (\%) found in different rural Nigerian populations as a result of two examinations of the urine, faeces and blood of each individual during the course of $\mathrm{I}$ year

\begin{tabular}{|c|c|c|c|c|c|c|c|}
\hline Parasite & Jarawaji & Mbanege & Bunga & $\begin{array}{l}\text { Tungan } \\
\text { Maidubu }\end{array}$ & Langai & Bero-Okuta & Tangaza \\
\hline Plasmodium falciparum & 47 & 47 & 49 & 34 & 30 & 39 & 26 \\
\hline Plasmodium ovale & 0 & I & 2 & 0 & I & 0 & $\circ$ \\
\hline Microfilariae & $\circ$ & 36 & 6 & 10 & 20 & 9 & $\circ$ \\
\hline Trypanosomes & o & 0 & o & $\circ$ & $\circ$ & 0 & $\circ$ \\
\hline $\begin{array}{l}\text { Schistosoma haemato- } \\
\text { bium }\end{array}$ & 6 & $\circ$ & 5 & 3 & 4 & 50 & Io \\
\hline Schistosoma mansoni & o & $\circ$ & $\mathbf{I}$ & $\mathbf{I}$ & $\circ$ & 5 & 2 \\
\hline Trichomonas hominis & 3 & 3 & 2 & $一$ & 4 & 一 & 一 \\
\hline Ankylostomes & I7 & 14 & 47 & 18 & 63 & 57 & 65 \\
\hline Ascaris sp. & $\circ$ & 36 & 3 & 8 & I4 & 6 & I I \\
\hline Entamoeba histolytica & o & 3 & 5 & 2 & 3 & 2 & 4 \\
\hline Entamoeba coli & 3 & $\circ$ & 2 & 0 & 5 & 2 & $\circ$ \\
\hline Trichuris trichura & 0 & 19 & 7 & - & 0 & $\mathbf{I}$ & - \\
\hline Giardia lamblia & 3 & $\circ$ & 2 & 2 & 4 & 7 & 3 \\
\hline Strongyloides sp. & o & 6 & 3 & 5 & 4 & 5 & - \\
\hline $\begin{array}{l}\text { Guinea-worm seen at } \\
\text { examination }\end{array}$ & 6 & $\circ$ & 3 & 0 & 3 & 6 & 0 \\
\hline $\begin{array}{l}\text { Onchocerca nodules } \\
\text { seen at examination }\end{array}$ & $\circ$ & 4 & 7 & 5 & 3 & 5 & 0 \\
\hline Taenia saginata & I & 0 & 2 & 2 & 4 & $\circ$ & $\mathbf{I}$ \\
\hline
\end{tabular}

The comparison of intake with requirement in the groups over 12 years of age (Table 4) showed three instances in which a discrepancy considerably greater than $\pm I 5 \%$ occurred, namely for the women of Jarawaji (143\%), Tangaza (68\%) and Tungan Maidubu (129\%). In the age groups from 4 to I 2 years it was the exception rather than the rule for the diets to supply enough calories to meet the suggested requirements, even though the adults' diets in the same community were satisfactory. No obvious correlation was found at any age between the calorie value of the diets and body-weight.

\section{DISCUSSION}

Weight, age, sex, mean annual external temperature, pregnancy (last trimester) and lactation have been taken into account in calculating the calorie requirements of seven different tribal groups of Nigerian peasants. Atmospheric relative humidity, which was found by Quenouille, Boyne, Fisher \& Leitch (I95I) to affect basal metabolism directly, was not allowed for by F.A.O.: Second Committee on Calorie Requirements (1957), and its variation from place to place in Nigeria has not been taken into account in this study, although the mean annual relative humidity is considerably higher in Bero-Okuta and Mbanege (80-85\%) than in the areas farther north $(55-65 \%)$. The main factor influencing the calorie requirement of a group of 
people is their energy expenditure, and the ratio of the estimated calorie value of the diets of these rural peasants to their calorie requirement as calculated by the methods recommended by F.A.O. (Table 4 ) must be examined from this point of view.

In two of the groups of males over 12 years of age the estimated calorie intake exceeded the calculated requirement by more than the limit of error of $\pm 15 \%$. These two groups, living in Jarawaji and Bunga, are cattle herdsmen and farmers who are physically very active and cover long distances on foot following their herds or walking to, and working on, their farms. Their mean weights were lower than those of the other five male groups of the same age, in spite of the fact that their diets supplied 116 and $120 \%$ of their estimated requirements $(54 \mathrm{kcal}$ and $53 \mathrm{kcal} / \mathrm{kg}$ body-weight respectively). The 'reference man' in his reference environment is allowed $49 \mathrm{kcal} / \mathrm{kg}$. On the other hand, in a yam-growing area, Mbanege, where men over 12 years of age obtained $94 \%$ of their estimated calorie requirement, the diet provided only $42 \mathrm{kcal} / \mathrm{kg}$ body-weight, yet they did not lose weight throughout the year. In Tungan Maidubu and Langai the calorie intake of men over 12 years of age was respectively 104 and $101 \%$ of requirements ( 47 and $43 \mathrm{kcal} / \mathrm{kg}$ body-weight). In all the areas mentioned so far the harvest had been satisfactory during the year of investigation and food supplies were plentiful. In Tangaza, however, the millet crop had been poor and the people did not eat as much as usual during the last 3 months of the year. This shortage lowered considerably the mean daily consumption figures for the year as a whole. In spite of this shortage the Tangaza men's diet provided $94 \%$ of calculated requirement, which was only $39 \mathrm{kcal} / \mathrm{kg}$ of their 'post-harvest' body-weight, and they lost an average of $2 \cdot 1 \mathrm{~kg}$ during the year. In the other area where food was short, Bero-Okuta, the diet supplied $37 \mathrm{kcal} / \mathrm{kg}$ of the 'post-harvest' body-weight, which was only $85 \%$ of the calculated requirement. Unfortunately these people were not re-weighed during the hungry pre-harvest period.

It is evident that the energy intake of the men of certain of these tribes, during a year when food supplies are available in reasonable quantity, is greater than that of the reference man, the energy intake of others being less when food supplies are low. The calorie values of certain diets may appear to be adequate if the ratio of intake to the requirement of a 'reference' subject is calculated, yet this level may be less than the normal energy expenditure of the consumers at times when food is plentiful.

The ratio of calorie intake to requirement among the groups of women over 12 years of age was more variable than that found for men of the same age. It must be remembered that it was impossible to differentiate the food consumption of pregnant and lactating women from that of the rest. In Jarawaji the women's diets provided approximately $53 \mathrm{kcal} / \mathrm{kg}$ body-weight, the same as that of their men, which was $143 \%$ of the calculated requirement. The F.A.O. reference woman is allowed $42 \mathrm{kcal} / \mathrm{kg}$. These Kanuri and Shuwa women travel on foot up to 20 miles to markets two or three times a week and work hard on the farms which are often several miles from their homes. At the other end of the scale were the Tangaza women, suffering from a food shortage, whose diets supplied $3 \mathrm{I} \mathrm{kcal} / \mathrm{kg}$ body-weight and only $68 \%$ of their calculated requirement. They lost $\mathrm{x} \cdot 9 \mathrm{~kg}$ in weight during the year, and were doing very little unessential physical work in the hungry period. In Tangaza it was obvious that 
the men consumed more than their fair share of the available food. In Langai, where the women obtained $95 \%$ of their estimated calorie requirement, the diet supplied $40 \mathrm{kcal} / \mathrm{kg}$ body-weight, compared with the reference woman's $42 \mathrm{kcal} / \mathrm{kg}$. The Mbanege women over 12 years of age received $95 \%$ of their requirement and $38 \mathrm{kcal} /$ $\mathrm{kg}$ body-weight, whereas at Bunga the women's diet supplied 102 \% of their requirement and $42 \mathrm{kcal} / \mathrm{kg}$. Neither the Mbanege nor the Bunga women performed much physical exercise over and above household duties. The Bero-Okuta women, on short rations, had $36 \mathrm{kcal} / \mathrm{kg}$ at $89 \%$ of requirement. The Tungan Maidubu women, who work hard on farms, consumed $129 \%$ of their calculated requirement.

Thus it is found, as for the men, that the women of certain tribes are more active than the 'reference woman', but that the diets of others, employed on ordinary household duties, provided amounts of energy which conform closely to the calculated requirement. In places where the men and women are not unduly energetic, e.g. Bunga and Mbanege for the women, and Mbanege and Langai for the men, the intake of calories approximates closely to the requirement calculated by the methods recommended by F.A.O. although the energy expenditure per $\mathrm{kg}$ body-weight is less than that of the reference individual. No relationship between body-weight and the energy value of the diets was noted.

In determining the mean calorie requirements of the female groups over 12 years of age, weights were recorded irrespective of pregnancy or lactation. Pooled data from all seven investigations showed that forty women who had been lactating for an average period of 9 months had a mean weight of $50.5 \mathrm{~kg}$, whereas the average weight of the 148 women neither lactating nor in the last trimester of pregnancy was $5 \mathrm{r} \cdot 9 \mathrm{~kg}$. The mean weight of the ten women in the last trimester was $56 \cdot \mathrm{I} \mathrm{kg}$. In Tangaza, where food was short and the women as a whole only obtained $68 \%$ of their calculated calorie requirement, the mean weight of eleven lactating women was $50.8 \mathrm{~kg}$, whereas twenty-one women neither lactating nor in the last trimester of pregnancy weighed $49 \cdot 3 \mathrm{~kg}$. In Bunga, where the women's diets supplied 102 \% of their requirements of calories, nine who had been lactating for an average period of 8 months weighed $48 \cdot \mathrm{I} \mathrm{kg}$, and twenty-nine neither in the last trimester nor lactating weighed $48.8 \mathrm{~kg}$. Thus it seems likely that food is distributed, and energy expenditure controlled, inside these groups of women in a manner which permits some weight gain towards the end of pregnancy, and prevents any undue loss of weight during lactation, irrespective of the overall availability of food supplies.

The results in Table 4 show that children of age 4-12 years obtained from their diets a smaller percentage of their calorie requirements by F.A.O. standards than did their parents. The parents in most of rural Nigeria do not realize the needs of growing children. The head of the family and then the other men tend to get priority for food over the women, and the children under the age of 13 years come last. This is one reason why it was so difficult to estimate the food consumption of boys and girls in the 10-12 years age group; they were becoming independent and might be away from home for many hours or even days hunting or fishing for food, which was cooked in the bush and never brought home to the compound. 
I. The food consumption of seven rural Nigerian peasant communities was estimated by methods which are explained, and the calorie value and nutrient composition of the diets were estimated from tables.

2. The calorie requirements of the age groups 4-6, 7-9, IO-I2 years, and of the males and females over 12 years of age were calculated by the methods suggested by the Second Committee on Calorie Requirements convened by the Food and Agriculture Organization of the United Nations (F.A.O.: Second Committee on Calorie Requirements, 1957), and were compared with the estimated calorie values of the diets eaten.

3. Good agreement between dietary calories and calorie requirements was obtained for men and women over 12 years of age in those communities whose way of life was not associated with considerable physical exertion, provided food supplies were not short.

4. Children of age $4^{-12}$ years were not given enough food to supply their calculated energy requirements, even when those over 12 years of age in the same community were adequately supplied.

5. It was apparent that food was shared between adult women in such a way as to prevent any marked loss of weight during lactation, which is usually prolonged, and to allow a reasonable gain of weight in the last trimester of pregnancy.

I am indebted to the Chief Medical Adviser to the Federal Government of Nigeria for permission to publish this paper. It is a pleasure to acknowledge the help of Mallam Abubakar Zukogi Bida and the members of the Medical Field Units of the Northern and Eastern Regions of Nigeria, and Mr S. Aigbokhaevbo's clerical assistance.

\section{REFERENCES}

Chatfield, C. (1953). F.A.O. nutr. Stud. no. 3, and ed.

Chatfield, C. (1954). F.A.O. nutr. Stud. no. Ir.

F.A.O.: Committee on Calorie Requirements (1950). F.A.O. nutr. Stud. no. 5.

F.A.O.: Second Committee on Calorie Requirements (1957). F.A.O. nutr. Stud. no. 5.

Leung, W. W., Pecot, R. K. \& Watt, B. K. (1952). Agric. Handb. U.S. Dep. Agric. no. 34.

Nicol, B. M. (1959a). Brit. F. Nutr. 13, 307.

Nicol, B. M. (1959b). W. Afr. med. F. 8, 18.

Platt, B. S. (1945). Spec. Rep. Ser. med. Res. Coun., Lond., no. 253.

Quenouille, M. H., Boyne, A. W., Fisher, W. B., \& Leitch, I. (I95I). Statistical Studies of Recorded Energy Expenditure of Man, Part I. Farnhan Royal, Bucks, England: Commonwealth Agricultural Bureaux. 